\title{
Kids' TV Programming in India: A Comparison of Gender Representation in Imports versus Locally Produced Programmes
}

\author{
By Ann Maria Rozario* \\ Vaageessan Masilamani ${ }^{\dagger}$ \\ Arulchelvan Sriram
}

\begin{abstract}
Kids' television channels in India air a mix of foreign and domestic programming. Comparisons between the two types of programming have been made on a variety of issues. A less talked about aspect though, is the differences or similarities in how both types of productions represent gender. This study aims to identify whether both genders are presented equally in domestic and foreign productions that airs in India. A content analysis of evening prime time programming on various kids' channels showed that the average ratio of male to female characters in an individual programme was 3:1. Males also outnumbered females in the programming of the majority of the countries. The gender ratio of almost all countries' productions (including India) did not reflect the gender ratio of their own population as well as that of India's census population. All three countries (USA, India and Japan) with the highest number of programmes in this sample had more titles with the names of male characters than females. Among the character roles, the role of the protagonist's ally/friend/co-worker was the most common role which all countries allotted to both genders. In terms of gender representation, American productions were the most similar to Indian productions.
\end{abstract}

Keywords: cartoons, children, gender, India television

\section{Introduction}

Kids' television programming in India is currently going through an exciting and blooming period where the 330 million kids aged 4-14 years (Bhagia, 2013a) are spoiled when it comes to choosing what to watch on television. With more than 20 channels at the national and regional level exclusively targeting kids with their specialized content (FICCI-KPMG, 2015), it is no wonder that the kids genre continues to be the most favourite type of programming for a majority of Indian kids (Adgully Bureau, 2016). Starting at the age of 18 months -2 years when they are first exposed to television (Hapkiewicz, 1979), kids fall in love with the medium that with a click of a button brings their favourite characters and stories into their living rooms.

Kids' programming in India consists of both animated (cartoons) and live action programmes that cater to younger and older kids respectively. The dynamic combination of captivating storylines, strong protagonists, futuristic settings, colourful visuals, catchy tunes and energetic voice talents in cartoons, draws and holds the attention of young kids in a manner that cannot be

\footnotetext{
* Research Scholar, Anna University, India.

$\dagger$ Research Scholar, Anna University, India.

* Assistant Professor, Anna University, India.
} 
replicated by any other media. Cartoons are for kids what soap operas are for adult women (Habib \& Soliman, 2015; Kaur, 2013). The twists and turns in plotlines keep both kids and their parents (who normally co-view) engrossed (Adgully Bureau, 2016). On the other hand, older kids are more attracted to live action shows that feature characters just like them, tackling problems just like theirs. All in all the number of animated cartoons and live action shows across the various kids' television channels are more than capable of providing Indian kids with endless hours of education and entertainment.

\section{Growth of the Kid's Genre}

Kids' television programming has come a long way since the early days of television in India when the state-run broadcaster- Doordarshan was the only channel that was beamed into homes across the country. Doordharshan allotted specific time slots as the children's hour and ran a mixture of indigenously produced programmes like Magic Lamp, Santakukdi, Gaayab Aaya, Malgudi Days and Khel Khilone along with acquired foreign cartoons like Duck Tales, The Jungle Book, Dennis the Menace, Chip \& Dale and Tales Spin among others (Kini, 2016). Despite the fact that the production of content within India was hindered by budget constraints, they were very much Indian in nature with the character names, looks and dialogs.

Despite television being introduced in the early 1960's (Agrawal, 1999), and the fact that private satellite channels after their introduction in the early 1990's were airing kids' programming for limited hours; the kids genre in India developed at a very slow pace. It was not until the year 1995 when Cartoon Network first started broadcasting in India, that the potential of kids' television programming was actually unlocked (Rashid, 2015). Cartoon Network with its international and never before seen library of cartoons revolutionized kids' programming in India. Broadcast solely in English in the initial years, by 1999 they started dubbing their cartoons in Hindi and Tamil in order to increase their reach (Thevar, 2014). The success of Cartoon Network caused more channels to jump into the fray and international giants like Nickelodeon and Disney soon set a base in India. Since then, the number of television channels for kids has only grown exponentially and now includes regional giants like Chutti TV and Kochu TV that telecast only in a single regional language (Bhagia, 2013a).

Ever since Cartoon Network started airing in India, there has been an open dependence by almost all channels on foreign programming (FICCI-KPMG, 2015) which was considered to be of superior quality to Indian productions in terms of the content, visuals and entertainment value. While American programming has long dominated the scene in India due to its vast collection of inexpensive kids' programming content (Lemish, 2007); it is now facing stiff competition from Japanese programming. The success of popular cartoons like Doraemon, Crayon Sin-Chan and Pokémon have seen them become the flagship shows of the channels in which they are aired (Kini, 2016). The significant reach of both American and Japanese content can be attributed to 
the increasing "Indianising" of content where a choice of multiple language feeds and Indian references within the dubbed dialogue help kids relate more to the content that they are seeing onscreen (Bhagia, 2013a).

The battle to increase the number of locally produced content has been long drawn out. The now defunct Splash TV was the first private player to buck the trend of relying solely on imported content when it offered as early as in 2001, Indian animated content through programmes like Pot Pourri and Indian folk tales (Kini, 2016). Doordharshan though had better success with its popular live action series "Shaktimaan" - the title character of which was popularly billed as India's first super hero (Roy, 2016). Despite such efforts, the stark reality was that it was too expensive to produce quality content given the poor technological infrastructure within the country.

The real renaissance for Indian produced kids' programming occurred much later when Pogo, Hungama and the Disney channel started tasting success with their locally produced Indian programming content. two popular shows that aired on Pogo - Chhota Bheem (an animated cartoon that first aired in 2008) and M.A.D. - Music Art Dance (a live-action show) were the trendsetters who proved that quality Indian content had the potential to become a hit (India Infoline News Service, 2009; Raghunath, 2012). Buoyed by this newfound success, more channels started investing in domestic programming content in both the animated and live-action domain. Eventually this lead to an increase in the percentage of domestic content in kids' programming from $10 \%$ in 2008 to $40 \%$ by the end of 2014 (FICCI-KPMG, 2015).

Today, the world of Indian mythology inspired stories easily coexists with the world of anime and the world of Disney among others. Indian characters like Chhota Bheem and Motu Patlu are as popular as foreign ones like Doraemon and Tom \& Jerry (FICCI-KPMG, 2015). This rich mix of Indian and foreign content has given kids an opportunity to be exposed to an assortment of cultures and values of different countries, in addition to their own.

\section{Television - A Socializing Agent}

The variety of kids' programming on offer has simply reinforced the fact that television is the greatest storyteller of modern times (Gerbner, Gross, Morgan, Signorielli, \& Shanahan, 2002). What is important to note though is that no matter from where the programmes originate, they all strike a chord with kids and adults alike. This is because they all share a common theme that good always triumphs over evil, and because more importantly they all provide an escape from the harsh realities of real life (Kaur, 2013).

Despite competition from other media, television is still the most favored pastime of kids in India (Adgully Bureau, 2016). Its tales continue to enchant kids and draw them into a world of make-believe while at the same time teaching them valuable lessons about life and the society in which they live. For a child, television is simply a reflection or extension of the society to which he/she belongs and a reliable repository of the knowledge required to 
successfully assimilate into society (Lemish, 2007). It is no wonder then that television is considered to be the most important socializing agent for a growing child who continuously looks towards it for answers on a wide variety of issues (Davies, 2001). Television plays a major role in setting the standards of how kids should or should not behave and many parents use television characters as references to drive home lessons on acceptable behavior (Knorr, 2015). Therefore in addition to learning how to interact with others, kids also start acquiring the social and cultural norms/values that are espoused in the programmes that they view. As a child actively engages with television content, he/she is subconsciously absorbing the dominant ideology that is present within it. The problem here is that given the fact that the critical skills and cognitive abilities of a child are not fully developed, it is worrying that kids simply accept the dominant TV discourses as real world truths (Merskin, 2008). Out of these, one of the powerful discourses that kids adopt in their own life is that of gender and its role in society.

\section{Learning about Gender}

Gender is essentially a social construct that kids start learning very early on in life (Brooks \& Hébert, 2006). Television along with other socializing agents like family, friends, school and religion play an influential role in the development of a child's gender schema (Aubrey \& Harrison, 2004; Holtzman $\&$ Sharpe, 2014). At the age of four, kids first develop the ability to distinguish between genders (Halim, Ruble, \& Tamis-LeMonda, 2013) and by the time kids turn seven, the concepts of sex role identity and sex-appropriate behaviors have already been learnt (Powell \& Abels, 2002). Given that on an average, a child spends nearly five hours viewing television on a daily basis (India Infoline News Service, 2010); a lot of this learning about gender can be traced back to a child's early and regular exposition to gendered content on television (Downs \& Harrison, 1985). Television characterization, in particular, is considered to be a powerful gender modeling tool (Durkin, 1985), especially when according to Bandura's social learning theory; kids identify themselves with the characters they see onscreen (Preiss, Mae Gayle, Burrell, Allen, Bryant, 2007). With multiple researches proving that kids do learn gender stereotypes and that their perceptions of sex-roles are influenced by the content they watch (Comstock \& Paik, 1991; Mayes \& Valentine, 1979), television's discourse on gender cannot be ignored.

It is, therefore, worrisome that previous research has revealed that females are grossly underrepresented in children's programming (Aubrey \& Harrison, 2004; Chu \& McIntyre, 1995; McMillin et al. 2008; Sternglanz \& Serbin, 1974). This figure reflects poorly on claims that women today are on an equal footing as men in various aspects of life. The symbolic annihilation of the female gender in kids' television programming sends out the message that their stories do not matter (Merskin, 2008). This conclusion is dangerous as now boys may wrongly develop an inflated sense of importance while girls start to 
feel like second-class citizens (Fitzpatrick \& McPherson 2010). The stereotypic portrayals of boys and girls in kids' programming only further aggravate the problem. Putting female and male character in slots that define the type of roles that society expects them to play is directly limiting the countless possible options that a child would otherwise be free to explore (Eick, 1998).

\section{Need for the Study}

Given that the presence of a gender in a country's media is one of the best signifiers of the gender dynamics within a country (Greenwood \& Lippman, 2010), we can assume that the gender discourse in kids' programming is a reflection of the dominant discourse of the country from where it originated. Therefore a close study of the number of male and female characters; and the roles that each portrays in kids' television programming could provide an insight into how each country packages gender constructs in its media messages. One earlier study, for example, analyzed all the imported kids' television cartoons in Hong Kong and found that female characters enjoyed far greater representation in cartoons produced in Japan than they did in cartoons produced in the US and Great Britain (Ahmed \& Wahab, 2014).

India continues to be dependent on foreign content and it is therefore, important to identify the dominant gender messages that the Indian child viewer is exposed to. It is also critical to settle the debate as to whether imports or desi programming provide kids with a more wholesome view of gender equality.

The aim therefore of this research is to assess if there is any major difference in how gender is represented in Indian produced kids' programming versus programming that is produced abroad. This study also seeks to understand whether gender representations in kids' television programmes vary based on the countries from where these programmes originate or if all countries present a similar gender discourse. The specific objectives are: 1) To check if both genders were represented equally in the programme titles of all countries; 2) To analyze the gender ratio of the main characters in the programmes produced by different countries; 3) To evaluate whether the gender ratio of India's population was better reflected in Indian than foreign programming; 4) To compare the ratio of male to female characters in programmes produced by each country, with their census ratio of the male to female population; 5) To identify the character roles commonly allotted to each gender by each country.

This study proposes the following hypotheses:

1. Every country has more male than female main characters in their programmes.

2. The ratio of male and female representation in programmes produced in India will reflect the male and female ratio of the Indian census population. 
3. The ratio of male and female representation in programmes produced abroad will not reflect the male and female ratio of the Indian census population.

4. Countries have more males than females in every character role in their programmes.

\section{Method}

A quantitative content analysis was conducted to gather data for this study. The authors decided to study the programming content of ten national channels and one regional channel that were available throughout the country via cable or through Direct-to-Home (DTH) services. Following are the kids' television channels selected for this study: 1) Cartoon Network; 2) Discovery Kids; 3) Disney Channel; 4) Disney Junior; 5) Disney XD; 6) Hungama; 7) Nick; 8) Nick JR.; 9) Pogo; 10) Sonic Nickelodeon and 11) Chutti TV (Regional Channel). As Chutti TV is a major player among all the regional kids' television channels, it has been included in this study.

The majority of these channels except Disney Channel (aimed at the whole Family) and Disney Jr. (aimed at kids aged 2-7 years) are targeted at children aged 4-14 years. At the time of the study, Nick Jr., was aired in two programming blocks. Between 6 AM - 7 PM, it targeted toddlers (as Nick Jr.) and from 7 PM $6 \mathrm{AM}$, the channel was rebranded as TeenNick (aimed at pre-teens and teens). With the exception of Chutti TV (broadcast in Tamil only), all of the channels are broadcast in English and multiple Indian languages.

The sample to be analyzed consisted of the programmes aired on the above channels. Therefore with the help of programming schedules, the authors identified all the different programmes that were aired on the eleven television channels between $6 \mathrm{PM}$ and $10 \mathrm{PM}$ in the week of February $22^{\text {nd }}$ (Monday) to February $28^{\text {th }}$ (Sunday) in 2016. Only programmes that were aired during the evenings were selected because evenings are considered to be the prime time for kids' television in India, with popular and flagship programmes of a channel mostly aired then (Agencyfaqs!, 2006).

When creating the final sample for this study, the authors only included programmes that were a series and narrative in nature (i.e. had characters that enacted a story) and eliminated formats like films, game shows, chat shows and magazine shows. The next stage was to remove duplicate entries of all programmes across channels. Therefore popular programmes like Dora the Explorer and Doraemon that aired on more than one channel were listed only once on the list of unique programmes. Finally, a check was made to ensure that each programme in our sample was produced by only a single country. This was done to ensure ease in comparing productions of various countries. Only one programme in the sample was a multinational production and it was removed from the study. Post all filtering, the final tally of unique programmes was 67 (Animated Series - 60; Live Action Series - 6; Combination of Animation \& Live Action Series - 1). 
The units of analysis for this study were the programmes themselves and the main characters within these programmes. Two coders analyzed the entire sample independently. Before commencing the coding process, both coders were given training on how to correctly code the video samples that were given to them. Three popular children's programmes (Doraemon; Chhota Bheem; Oggy and the Cockroaches) were used as examples to familiarise the coders with how to first identify the main characters and later how to conclusively determine a character's gender and role. The coders' understanding of the various variables to be studied was then tested and fine-tuned by giving them 10 animated videos (not included in final sample) to code. Post - training, each of the two coders viewed five different discrete narratives of every programme series $(\mathrm{N}=67)$. A discrete narrative is essentially a single story in a series akin to an episode in a live-action programme. Reliability analyses were conducted on $20 \%(\mathrm{~N}=14)$ of the 67 unique programmes in this study. Five discrete narratives for each of the 14 programmes were double coded by both coders independently to obtain intercoder reliability. Cohen's kappa was calculated at 0.93 .

In the first phase of coding, the coders identified the country of production for each of the programmes in the final sample by visiting the websites of each programme and by identifying the location of the production house. There were nine countries in all including India where the programmes in this sample were produced.

In the second phase of coding, the gender and roles of all the main characters in a series were coded. The main character for the purpose of this study was defined as an individual who appeared in multiple episodes in a series; who played an important role in the advancement of the storyline and who could otherwise be considered as a prominent/regular member in the cast of characters of a programme. The gender of the character was identified based on their appearance, voice, name and how they were perceived by the other characters. In cases where the coders could not identify the gender of a character, information on the character's gender was obtained from the website of either the programme or the channel on which it aired. A total of 596 main characters were identified in the sample. As gender could not be determined for six characters, they were dropped from the sample and the final count of main characters that were analyzed was 590.

Based on how a character was depicted in the series, they were identified as playing any one of the following roles: 1) Protagonist; 2) Antagonist/Antagonist's Henchman; 3) Bully/Rival/Frenemy; 4) Protagonist's Ally/Friend/Co-Worker; 5) Protagonist's Family Member and 6) Other Roles. For example, some of the main characters in the Indian production "Roll No. 21" were classified as follows:

- Kris (M) - Protagonist

- Kanishk (M) - Antagonist/ Antagonist's Henchman

- Suparna (F) - Antagonist/ Antagonist's Henchman

- Pinky (F) - Protagonist's Ally/Friend/Co-Worker

- Madhu (M) - Protagonist's Ally/Friend/Co-Worker

- Golu (M) - Bully/Rival/Frenemy 
After individually coding the gender and roles of all the main characters; the coders compared their findings. Discrepancies were discussed and additional three discrete narratives were viewed together if necessary in order to arrive at a consensus. The data finalized by the coders was then tabulated and appropriate statistical tests were carried out.

\section{Results}

\section{Gender Representation in the Titles of Programmes}

During the process of coding, 67 unique programme titles and the country of production of each were identified. The three countries with the most number of programmes in the sample were USA $(\mathrm{N}=33)$, India $(\mathrm{N}=17)$ and Japan $(\mathrm{N}=8)$. The remaining nine programmes made up $13.43 \%$ of the analyzed sample and were from the following countries: UK, France, Ireland, Italy, Malaysia and Singapore (Table 1).

In the next stage, the use of character names in the titles was analyzed to get an understanding of the prominence given to each gender in the titles of the programmes. Five countries (USA, India, Japan, France and Malaysia) had a male character's name in the majority of their programme titles. Only three countries (USA, India and UK) had the names of female characters in at least one of their programme titles. All countries except France and Malaysia had some programmes with titles that had no character names in them. There were no programmes in the sample which had a combination of male and female character names in their titles.

A closer look at the programme titles from USA, India and Japan revealed that while the USA had male character names in only $51.52 \%$ of its titles, the two Asian countries had a male character's name in a little more than $70 \%$ of their titles. All three countries also had more titles with no character names than titles with names of female characters (Table 1).

Table 1. Gender Representation in the Titles of Programmes

\begin{tabular}{|l|c|c|c|c|}
\hline $\begin{array}{l}\text { Country of } \\
\text { Production }\end{array}$ & $\begin{array}{c}\text { No. of } \\
\text { Programme } \\
\text { s }\end{array}$ & $\begin{array}{c}\text { Titles with } \\
\text { Male Character } \\
\text { Names }\end{array}$ & $\begin{array}{c}\text { Titles with } \\
\text { Female } \\
\text { Character } \\
\text { Names }\end{array}$ & $\begin{array}{c}\text { Titles with No } \\
\text { Character } \\
\text { Names }\end{array}$ \\
\hline USA & 33 & $17(51.51)$ & $4(12.12)$ & $12(36.36)$ \\
\hline India & 17 & $12(70.9)$ & $1(5.89)$ & $4(23.53)$ \\
\hline Japan & 8 & $6(75)$ & $0(0)$ & $2(25)$ \\
\hline UK & 3 & $1(33.3)$ & $1(33.3)$ & $1(33.3)$ \\
\hline France & 2 & $2(100)$ & $0(0)$ & $0(0)$ \\
\hline Ireland & 1 & $0(0)$ & $0(0)$ & $1(100)$ \\
\hline Italy & 1 & $0(0)$ & $0(0)$ & $1(100)$ \\
\hline Malaysia & 1 & $1(100)$ & $0(0)$ & $0(0)$ \\
\hline Singapore & 1 & $0(0)$ & $0(0)$ & $1(100)$ \\
\hline Total & $\mathbf{6 7}$ & $\mathbf{3 9 ( 5 8 . 2 )}$ & $\mathbf{6 ( 8 . 9 5 )}$ & $\mathbf{2 2}(\mathbf{3 2 . 8 3})$ \\
\hline
\end{tabular}

Note: ( ) - Refers to row percentage. 


\section{Gender Distribution of the Main Characters}

The first hypothesis was tested with the help of chi-square analyses. The total number of male and female main characters in programmes produced by each country was compared individually. Males outnumbered females in the programmes produced by five out of the nine countries. There was a significant difference between the number of male and female characters in programmes produced by USA $\left(\chi^{2}=75.36, d f=1, p<0.001\right)$ India $\left(\chi^{2}=44.55, d f=1, p<\right.$ $0.001)$, Japan $\left(\chi^{2}=10.89, d f=1, p<0.005\right)$, France $\left(\chi^{2}=4.45, d f=1, p<0.05\right)$ and Malaysia $\left(\chi^{2}=4.45, d f=1, p<0.05\right)$. In contrast, there was no significant difference between the number of male and female characters in programmes produced by the UK $\left(\chi^{2}=0.25, d f=1, p<0.05\right)$ and Italy $\left(\chi^{2}=0.048, d f=1, p<\right.$ $0.05)$. A chi-square analysis could not be conducted for the values of Singapore and Ireland. Therefore the hypothesis that males would outnumber females in the programmes of all countries was only partially supported (Table 2).

A chi-square analysis of the all the main characters in the sample irrespective of the country of origin showed that $73.39 \%(\mathrm{~N}=433)$ of all the main characters were male in comparison to $26.61 \%(\mathrm{~N}=157)$ that were female, $\chi^{2}=129.11, d f=$ $1, p<0.001$. Therefore overall, there are more male than female main characters (Table 2).

Table 2. Gender Distribution of the Main Characters in Programmes Produced by Different Countries

\begin{tabular}{|l|c|c|c|c|c|c|}
\hline \multirow{2}{*}{$\begin{array}{l}\text { Country of } \\
\text { Production }\end{array}$} & \multicolumn{1}{|c|}{ Main Characters } & \multicolumn{2}{|c|}{ Male } & \multicolumn{2}{c|}{ Female } \\
\cline { 2 - 7 } & Total & $\begin{array}{l}\text { Average per } \\
\text { Programme }\end{array}$ & Total & $\begin{array}{l}\text { Average per } \\
\text { Programme }\end{array}$ & Total & $\begin{array}{l}\text { Average per } \\
\text { Programme }\end{array}$ \\
\hline USA & 279 & 8.45 & $212(75.99)$ & 6.42 & $67(24.01)$ & 2.03 \\
\hline India & 166 & 9.76 & $126(75.9)$ & 7.41 & $40(24.1)$ & 2.35 \\
\hline Japan & 72 & 9 & $50(69.44)$ & 6.25 & $22(30.56)$ & 2.75 \\
\hline UK & 16 & 5.33 & $9(56.25)$ & 3 & $7(43.75)$ & 2.33 \\
\hline France & 11 & 5.5 & $9(81.82)$ & 4.5 & $2(18.18)$ & 1 \\
\hline Ireland & 5 & 5 & $2(40)$ & 2 & $3(60)$ & 3 \\
\hline Italy & 21 & 21 & $10(47.62)$ & 10 & $11(52.38)$ & 11 \\
\hline Malaysia & 11 & 11 & $9(81.82)$ & 9 & $2(18.18)$ & 2 \\
\hline Singapore & 9 & 9 & $6(66.67)$ & 6 & $3(33.33)$ & 3 \\
\hline Total & $\mathbf{5 9 0}$ & $\mathbf{8 . 8}$ & $\mathbf{4 3 3 ( 7 3 . 3 9 )}$ & $\mathbf{6 . 4 6}$ & $\mathbf{1 5 7}(\mathbf{2 6 . 6 1 )}$ & $\mathbf{2 . 3 4}$ \\
\hline
\end{tabular}

Note: ( ) - Refers to row percentage.

The average number of main characters across all programmes irrespective of the country of production was 8.8 with 6.46 males and 2.34 females. This figure is very close to the average number of main characters in programmes produced by the USA (8.45), which also had an average of 6.42 males and 2.03 females per programme. Given that programmes from the USA constituted $49.25 \%$ of the sample, this is a reasonable finding. The other two countries India and Japan which have the second and third most number of programmes in this sample have a similar average of 9.76 and 9 main characters per programme respectively. Keeping with the trend of programmes produced by USA, the average number of female main characters produced by India and 
Japan are 2.35 and 2.75 respectively. Only Italy and Ireland which have produced one programme each in the sample have a higher number of females than males in their programmes. With the exception of France that averages one female main character per programme, all other countries have a minimum average of two female main characters per programme (Table 2).

\section{Gender Comparisons between a Country's Population and its Programme's Characters}

The main characters in any programme have a consistent presence throughout its series. They, therefore, can be considered as the representative population of a programme series. In order to check whether the programmes produced by each country accurately reflected the gender distribution ratios of their country's population; census data from each of the countries was compared with the data about their main characters identified in this study. The findings showed that with the exception of Italy, all countries had a high level of inconsistency between their ratio of male and female population and their ratio of male and female main characters. Italy's gender distribution in its television programmes bore the closest resemblance to its census population. Though it also had variations between its gender representations in its television programmes and its census population, the level of difference was only $0.94 \%$ (Figure 1 ).

Only four countries (India, Malaysia, Ireland and Italy) had the same gender outnumbering the other in both their census population and in their programme population. Though there was a higher percentage of males than females in India's census population and in its programmes, the percentage of male characters exceeded the percentage of the male population by $24.43 \%$. Therefore the hypothesis 2 that the ratio of males to females in programmes produced in India would match that of the ratio of the male and female population in the country was not supported. Indian programmes by making around $3 / 4^{\text {th }}$ of their characters male are presenting a male-dominated world to their viewers which are a far cry from the actual gender ratios in the country. With Malaysia too, males outnumber females in both the census population and in its programmes. The domination of males on television $(81.82 \%)$ though is much higher than in its census population (51.74\%). Finally, Ireland and Italy were the only two countries where the percentage of females was more than the males in both their census population and in their programmes (Figure 1).

Out of the nine countries identified in this study, all countries with the exception of India and Malaysia had a higher percentage of female than male population. In contrast, $73.39 \%$ of all the main characters in the sample were male. Therefore when in reality, females outnumber males; in television programmes for kids, males outnumber females.

Out of the 67 programmes aired in India, 50 are produced abroad. $82 \%$ of the 50 programmes were produced by USA and Japan. Therefore to test hypothesis 3 , only the gender ratio of the programmes produced by these two countries was compared with India's census population. The gender ratio of 
programmes produced in both the USA and Japan was very different from that of the Indian population. Therefore hypothesis 3 that the gender ratio of the Indian population would not be reflected in the programmes produced abroad was accepted.

Figure 1. Gender Comparisons Between Characters in Programmes Produced by a Country with its Population

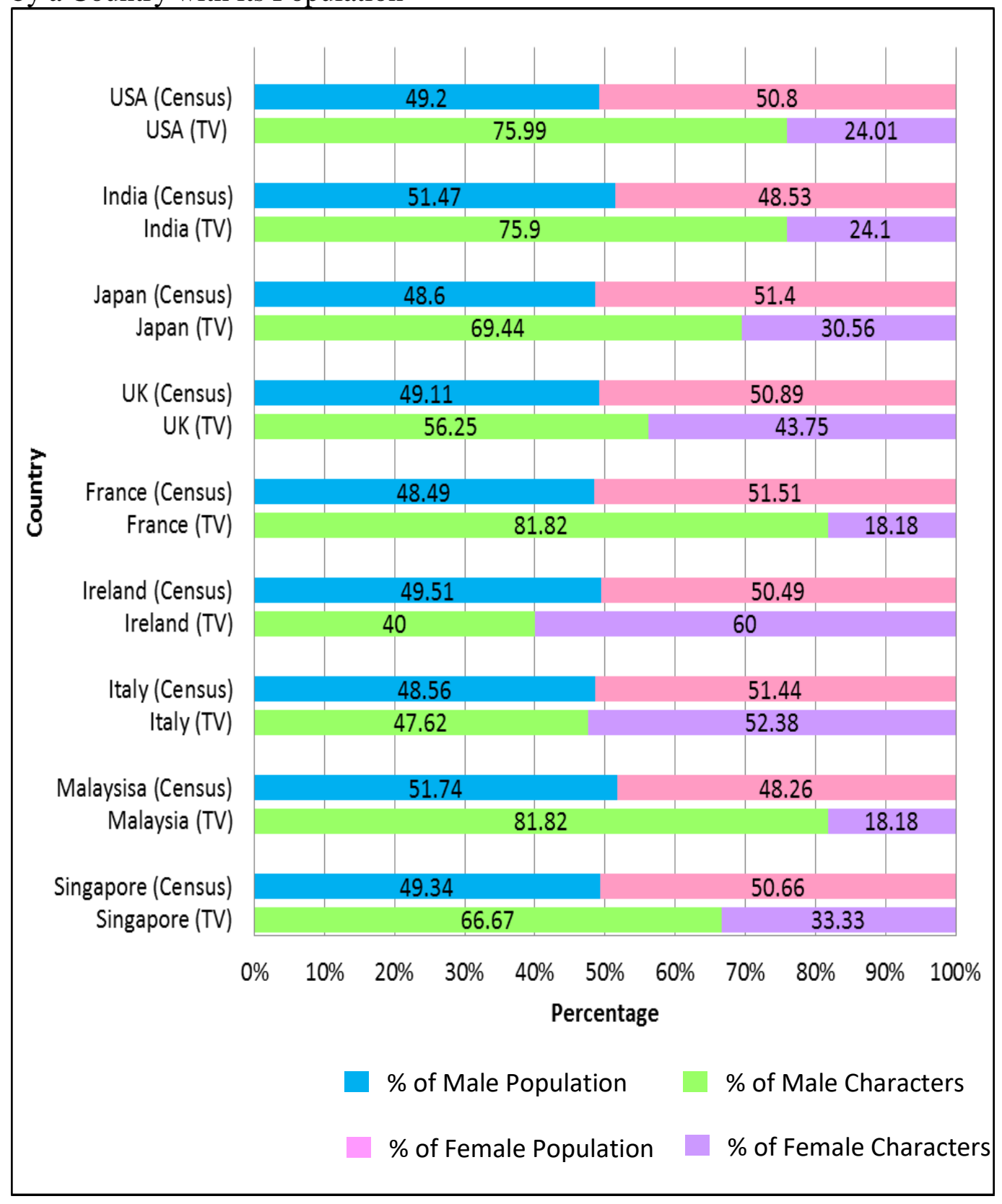




\section{Roles Commonly Allotted to Male and Female Characters}

An analysis of the roles allotted to each gender by different countries shows that there are both similarities and variations between countries in their choice of roles (i.e. the role of protagonist, antagonist/antagonist's henchman, bully/rival/ frenemy, ally/friend/co-worker of the protagonist and family member of the protagonist) for each gender. The main characters that played roles other than those above have not been included in the analysis of the most and least common role in each country's programmes (Figures $2 \& 3$ ).

Programmes produced in the USA have both males and females in all the five different roles. Males were found the least in the roles of bully/rival/ frenemy and in the role of the protagonist's family member. Females, on the other hand, had the least presence in the roles of bully/rival/frenemy and antagonist/antagonist's henchman.

When it came to India, males were cast in all five character roles in its various programmes. Female characters were not cast at all only in the role of the bully/rival/frenemy. The top two roles played by males were that of an ally/ friend/co-worker and that of a protagonist. While the highest number of females played the role of an ally/friend/co-worker, the second highest number of females was a family member of the protagonist.

Like India, one other Asian country on the list, Japan had males playing all five roles. Males and females were cast the most in the role of an ally/friend/ coworker. There were no female protagonists and bullies/rivals/frenemies. Males, on the other hand, were found the least in the role of a family member.

In the programmes produced by the UK, males played all the other four roles except that of the bully/rival/frenemy. The female characters, in contrast, were restricted to playing the roles of a family member, an ally/friend/co-worker and the protagonist.

The analysis of French programming showed that there are males in every character role except in that of the antagonist/antagonist's henchman. Females on the other hand in this sample were limited to playing a single role, that of an ally/friend/co-worker.

Only a single programme from Ireland formed part of this study's sample. In this country's production, male characters were found only in the role of the ally/ friend/co-worker of the protagonist. Female characters too had a limited choice of roles - either that of an ally/friend/co-worker or of a protagonist.

In the Italian programme that was analyzed, females were cast in three different roles (protagonist, antagonist/antagonist's henchman and ally/friend/ coworker) when compared to males who were cast in only two roles (antagonist/ antagonist's henchman and ally/friend/co-worker).

With the exception of the role of the family member of the protagonist, males played all other roles in the Malaysian programme that was analyzed.

Finally, the analysis of the programme from Singapore revealed that males played only three of the five roles that were analyzed in this study; the role of the protagonist, antagonist/antagonist's henchman and ally/friend/co-worker. The roles of females in this programme were restricted to that of the antagonist/ antagonist's henchman and ally/friend/co-worker. 
Figure 2. Character Roles Allotted to Males by Different Countries

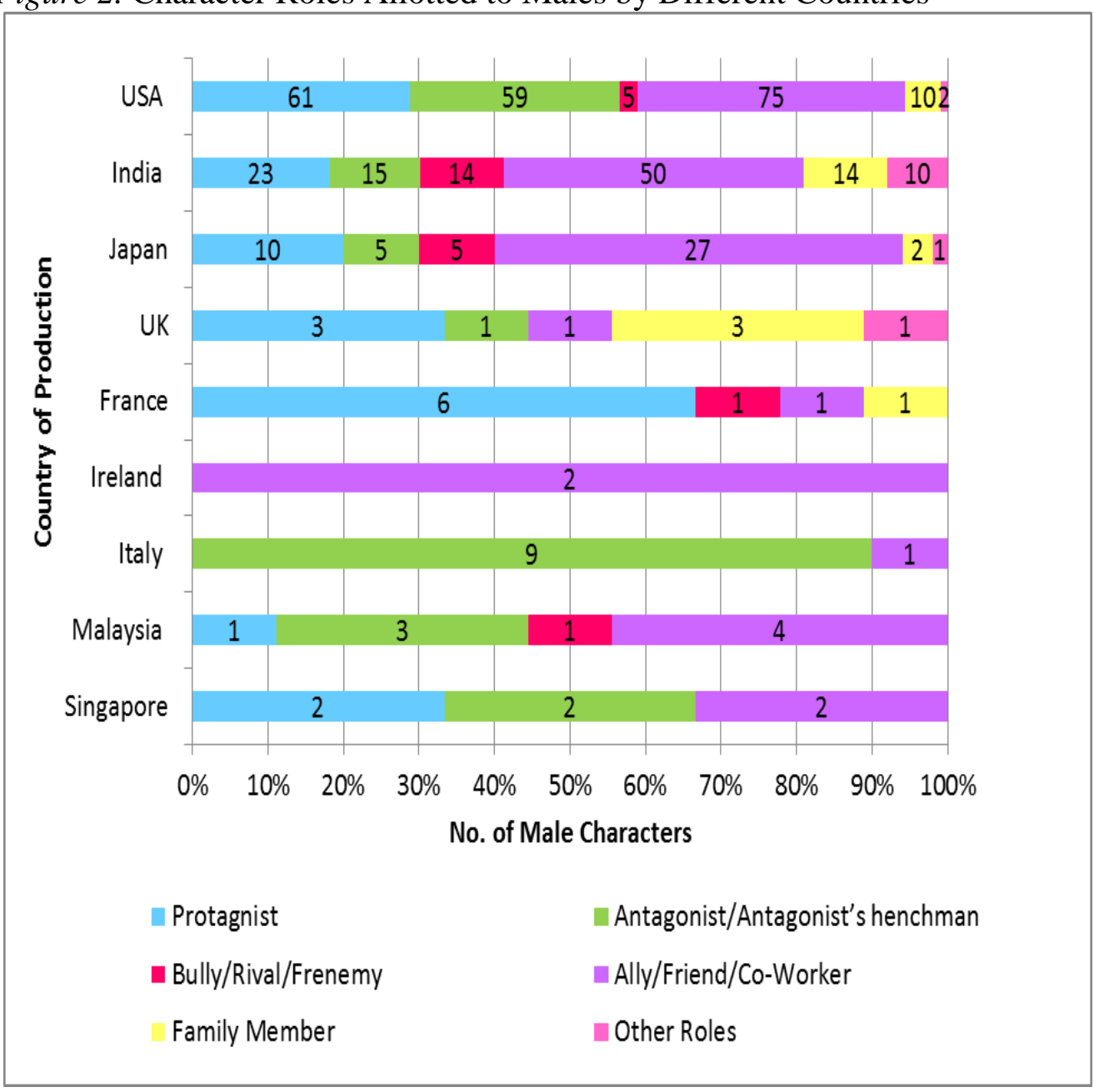

Therefore, among the various character roles in this study, the only role in which all the countries had both male and female characters in was that of the protagonist's ally/friend/co-worker. The least common roles allotted to both males and females were the same - that of the protagonist's family member and the bully/rival/frenemy. Overall, the above findings about gender representation in the programmes produced by different countries reveal that Indian viewers get to see females in more diverse roles in programmes from USA than from other countries (Indian productions included). In contrast, there are three countries (USA, India and Japan) whose programmes feature males in all the variety of roles included in this study (Figures $2 \& 3$ ).

Comparisons between USA, India and Japan's gender representation in character roles. To address the hypothesis 4 that males would outnumber females in all character roles in the programming of different countries; chisquare analyses of gender representation in programmes produced only in the USA, India and Japan was conducted. This was because all three countries had the most number of programmes in this sample and together made up $86.57 \%$ of the overall sample. 
Figure 3. Character Roles Allotted to Females by Different Countries

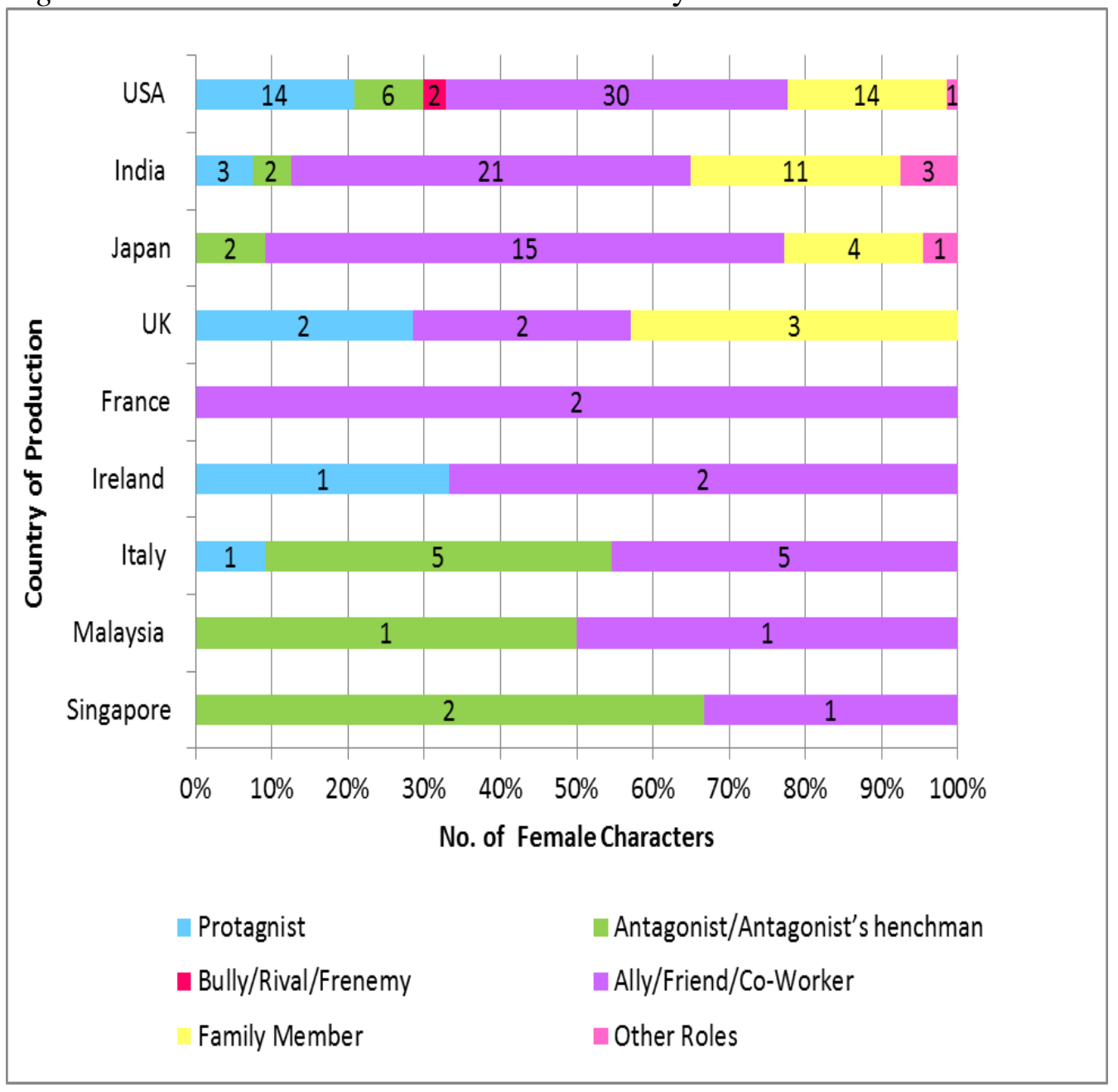

Role of protagonist. Males outnumbered females in the role of the protagonist in the programmes produced by all three countries - USA $\left(\chi^{2}=29.45\right.$, $d f=1, p<0.001)$, India $\left(\chi^{2}=15.38, d f=1, p<0.001\right)$ and Japan $\left(\chi^{2}=10, d f=1\right.$, $p<0.005)$ (Table 3).

Role of antagonist/antagonist's henchmen. Characters in the role of the antagonist/ antagonist's henchmen are more likely to be male than female. For both USA $\left(\chi^{2}=43.22, d f=1, p<0.001\right)$ and India $\left(\chi^{2}=9.94, d f=1, p<0.005\right)$, there was significant difference between their number of male and female characters. Chi-square analysis could not be conducted with the values for Japan (Table 3).

Role of bully/rival/frenemy. India was the only country where there were more male than female bullies/rivals/frenemies, $\chi^{2}=14, d f=1, p<0.001$. The chisquare analysis could not be conducted for the values in this role for USA and Japan (Table 3).

Role of ally/friend/co-worker. Female allies/friends/co-workers were outnumbered by males in programmes produced by both USA $\left(\chi^{2}=19.29, d f=1\right.$, $p<0.001)$ and India $\left(\chi^{2}=11.85, d f=1, p<0.001\right)$. There was no significant 
difference between the number of males and females in the Japanese productions $\left(\chi^{2}=3.43, d f=1, p<0.005\right)$ (Table 3$)$.

Role of family member. Males did not dominate in the role of the protagonist's family member as the chi - square analyses revealed that there was no significant difference between the number of male and female characters in this role in programmes produced by the USA $\left(\chi^{2}=0.67, d f=1, p<0.005\right)$ and India $\left(\chi^{2}=0.36, d f=1, p<0.005\right)$. Chi-square analysis could not be conducted for Japan's values (Table 3).

The above results show that males outnumbered females only in some character roles. Therefore the hypothesis 4 that countries had more males than females in every character role is only partially supported. The programmes produced in the USA are more similar to India than Japan in terms of their preference for a particular gender in various character roles.

Table 3. Gender Representation in Each Character Role

\begin{tabular}{|c|c|c|c|c|c|c|c|c|c|}
\hline \multirow[b]{2}{*}{$\begin{array}{l}\text { Character } \\
\text { Role }\end{array}$} & \multicolumn{3}{|c|}{ USA } & \multicolumn{3}{|c|}{ India } & \multicolumn{3}{|c|}{ Japan } \\
\hline & $\begin{array}{c}\text { Total } \\
\text { (N) }\end{array}$ & $\begin{array}{c}\text { Male } \\
(\%)\end{array}$ & $\begin{array}{c}\text { Female } \\
(\%)\end{array}$ & $\begin{array}{c}\text { Total } \\
\text { (N) }\end{array}$ & $\begin{array}{c}\text { Male } \\
(\%)\end{array}$ & $\begin{array}{c}\text { Female } \\
(\%)\end{array}$ & $\begin{array}{c}\text { Total } \\
\text { (N) }\end{array}$ & $\begin{array}{c}\text { Male } \\
(\%)\end{array}$ & $\begin{array}{c}\text { Female } \\
(\%)\end{array}$ \\
\hline Protagonist & 75 & 81.33 & 18.67 & 26 & 88.46 & 11.54 & 10 & 100 & 0 \\
\hline $\begin{array}{l}\text { Antagonist/ } \\
\text { Antagonist's } \\
\text { Henchmen }\end{array}$ & 65 & 90.77 & 9.23 & 17 & 88.24 & 11.76 & 7 & 71.43 & 28.57 \\
\hline $\begin{array}{l}\text { Bully/Rival/ } \\
\text { Frenemy }\end{array}$ & 7 & 71.43 & 28.57 & 14 & 100 & 0 & 5 & 100 & 0 \\
\hline $\begin{array}{l}\text { Ally/Friend/ } \\
\text { Co-Worker }\end{array}$ & 105 & 71.43 & 28.57 & 71 & 70.42 & 29.58 & 42 & 64.29 & 35.71 \\
\hline $\begin{array}{l}\text { Family } \\
\text { Member }\end{array}$ & 24 & 41.67 & 58.33 & 25 & 56 & 44 & 6 & 33.33 & 66.67 \\
\hline Other Roles & 3 & 66.67 & 33.33 & 13 & 76.92 & 23.08 & 2 & 50 & 50 \\
\hline
\end{tabular}

\section{Discussions}

Kids' programming in India continues to be dominated by animated content. With nearly $90 \%$ of the programming aired in the evenings being animated, one can safely say that the lure of cartoons is still as appealing and magical as it was years ago. Also, channels prefer animated content because they have a repeated value when compared to live action. Kids can watch them again and again and still be entertained. The use of animated content, therefore, offers programming heads the opportunity to recycle old episodes while occasionally introducing bursts of new programming (Bhagia, 2013a).

The use of animated content also comes with its share of challenges. It is expensive, takes more time to produce and requires strong technical infrastructure to produce quality cartoons. Given that the return on investment (ad revenue) for kids' programming in India is comparatively very low and not in line with its viewership levels (Kohli-Khandekar, 2014), channels do not wish to invest much in the production of original content. They have instead resorted to importing content from abroad as it makes more economic sense 
and also because kids do not mind seeing non-Indian characters (Bhagia, 2013b). This dependence on imported content is reflected in results of this study which show that in the evenings, $74.63 \%$ of the kids' programming aired in India is imported.

According to the FICCI-KPMG's Indian Media and Entertainment Industry Report, $42 \%$ of all the animated shows aired in India are imported from the USA (2015). When it comes to evening prime time programming alone, this study found that the USA still remains the most favored country of import as nearly half of the programmes $(49.25 \%)$ analyzed in this study were produced there. This result is expected since, nine out of eleven of the kids' channels whose programmes were analyzed in this study are owned or branded by American based companies, who recycle content produced for the American audience in India. Despite this heavy dependence on American content, locally produced Indian content is not far behind. In recent years, Indian produced kids' programming has come into the limelight and has proven to be a financial success (FICCI-KPMG, 2015). A fact reflected in the finding that $25.37 \%$ of the sample was content produced in India. Japanese that produced programmes or anime are the third biggest player in the market. Though the number of Japanese programmes was only eight in this sample, it must be noted that they get significant run time with discrete narratives of the same series being continuously telecast for more than an hour even during evening prime time. The number of programmes from the other six countries in this sample is relatively much lower but their infusion into daily programming needs to be encouraged as it offers kids a chance to sample quality programming from across the world.

A child's increased exposure to television and their comparatively limited exposure to the real world ensure that they can reel off more character/show names than that of real people. The programme titles, therefore, are an important aspect of a programme that helps in recall and quick identification. In addition to these two functions, programme titles also provide some sort of information about what or whom the programme is about. Therefore the presence of a character's name in the title signifies his/her importance to the plot. In this study, the majority of the countries (India included) showed a preference for having male character names in the title followed by the use of neutral titles (i.e. Titles that had no character names). Therefore most programme titles themselves were gender biased. Additionally, none of the programmes in this sample had both a male and female character name in their titles. This could be viewed as a hesitation towards presenting males and females as equals.

One could conclude that all countries irrespective of their social realities seem to be promoting the idea that only male characters are the key drivers of story plots. This could leave young girls who are exposed to such a selection of programming to develop a false notion that interesting and amazing things happened only with boys and that girls should remain as mere spectators. Given that the choice of which programmes to telecast is in the hands of programming heads, one can decipher from the large number of male-centric 
titles that a conscious decision has been made by channels executives to promote programmes with male leads. This could be due to the popular justification that females are more willing than males to watch programming that featured the opposite gender (Aubrey \& Harrison, 2004).

Even if this reasoning was accepted, it does not justify the finding that there are more male than female main characters overall in the sample analyzed. The main characters in any programme represent a minisociety/population amongst which the protagonist lives. The average ratio of male to female characters in kids' programming that is aired in India is 3:1. Therefore, kids in India are being constantly exposed to programming where they see a male lead living in a world where there are more males than females and where males have more important roles to play. The psychological and social impact of exposing kids to such gendered biased content, even when they have not yet developed the ability to differentiate television depictions from reality (Nikken \& Peeters, 1988), seems to be constantly overlooked. Our finding that males dominate kids' programming in India is in line with similar research findings on kids' programming across the world. Therefore with this fact being well known, it is surprising that content producers continue to shy away from presenting a more gender balanced world to their young viewers.

\section{Social Reality versus Television Depictions}

Not all countries in this sample had more males than females in their productions. This led the authors to question whether the media products of a country could be considered as a reflection of its social and cultural values. We used a two-pronged approach to help solve this query. First, a comparison of the gender ratio of each country's programme population with its census population revealed that there was a huge discrepancy between the two for all countries except Italy. This mismatch in the gender ratios of the census and TV population shows a clear trend of programming of most countries to be biased towards representing one gender more (mostly the male gender). This is despite the fact that for all countries, the gender ratio of their population is more or less equal.

In the second part of the enquiry, a check was made to ascertain whether countries that have been highly rated as being gender equal in their society, represented both genders equally in their productions. The UNDP's Gender Inequality Index (GII) that ranks countries in terms of gender equality (Table 4) has ranked the USA and Japan (the top two foreign contributors to kids' programming in India) highly at No. 55 and 26 respectively (United Nations Development Programme - UNDP, 2015). Therefore it was surprising that the level of gender equality present in the society of both these nations was not reflected in its programming that showed a bias towards males. On the other hand, India which scored poorly with a comparatively low rank of 130 (United Nations Development Programme - UNDP, 2015) also had a significant level of inequality in its gender ratio of programme characters. Based on the findings from both analyses, we postulate that in the case of kids' programming, most countries do not reflect their social realities in terms of gender representation. 
Table 4. UNDP's Gender Inequality Index Rank in Terms of Gender Equality

\begin{tabular}{|l|c|}
\hline Country & GII Rank 2014 \\
\hline USA & 55 \\
\hline India & 130 \\
\hline Japan & 26 \\
\hline UK & 39 \\
\hline France & 13 \\
\hline Ireland & 21 \\
\hline Italy & 10 \\
\hline Malaysia & 42 \\
\hline Singapore & 13 \\
\hline
\end{tabular}

Source: From United Nations Development Programme (UNDP)'s Gender Inequality Index, 2015.

A quick comparison of domestic and foreign productions to see which fared better in gender representation showed that the level of gender representation of programmes from USA and Japan (who make up 82\% of the imported content) is surprisingly very similar to gender representation ratios in Indian productions which are biased towards males. This preferential treatment for males over females extended to the casting of each gender in various character roles. Productions of USA, in particular, had more males in the same set of roles (protagonist, antagonist/antagonist's henchmen and allies/friends/ co-workers) as Indian productions. Programmes from India therefore, seem to have adopted the American template of giving males greater representation in kids' programming. Considering that American kids' programming has long been dominating the Indian TV space, it is of no wonder that gender representation in Indian programming is mimicking American standards.

The lack of diversity in roles for females, when compared to males, has also been identified in this study. Therefore not only is the presence of females in most programmes limited, they are also mostly cast in the role of the protagonist's ally/friend/co-worker. Reducing the presence of females in certain roles or restricting their presence to other roles is a worrying trend. Additionally, the placement of only male characters in powerful and influential roles could result in a young child developing a warped view of gender roles a development that could then result in serious consequences in later life (Shehab, 2008). It is, therefore, worrying that many kids' programmes today lack strong female characters. The role of the protagonist especially seems to be a male-dominated domain with most productions (Indian and foreign) having male leads. This paucity of female protagonists is a worrying trend and an infusion of female protagonists is urgently needed in kids' evening programming. Such an effort would be beneficial to both young boys and girls as it would challenge their existing ideas about gender roles and open up their minds to perceive the other sex in terms other than that of popular gender stereotypes. 


\section{Conclusion}

Kids' programming throughout the world shares one important factor They all try to impart good human values to kids while keeping them entertained. It is, therefore, worrying that this study's results show that there is a strong hint of a patriarchal discourse in both Indian and foreign productions. Foreign productions that are chosen to be aired in India not only fail to reflect the social reality of their country of origin, they also fail to reflect the reality of the country in which they are aired as well. Given that the Indian Government unlike in other countries, does not mandate television channels to ensure that a fixed percentage of their programming is made up of locally produced content; the dependence on imported programming is most likely to continue.

The authors recommend that channels could stipulate the maintenance of a stipulated gender ratio in all the new programmes that they commission in the future. India also needs to set up an independent agency/watchdog that monitors kids' programming within the country. Such an agency could in consultation with various stake holders (Example: The Government, Kid's Channels, Parents, etc.) engage in media advocacy and draw up a set of guidelines to ensure that kids are being exposed to quality content that is entertaining, educative and empowering.

The authors hope that this study spurs domestic content creators and channel programming heads to work together towards ensuring more equitable representations of gender in kids' programming. This move could, in the long run, establish gender balanced programming as the norm to be emulated.

\section{Limitations}

This study covered only programming on a little more than half of the total television channels for kids in India. The popular channel "Animax" that airs only Japanese anime could not be selected for the study as it was not commonly available across all DTH providers and cable at the time of the study. Future studies could include this channel and more regional channels to get a better look at how different countries present gender in their programmes.

\section{References}

Adgully Bureau. (2016, May 13). Indian kids wield an annual spending power of Rs 22,594 cr: Turner New Gen Study. Retrieved from goo.gl/nTspkz.

Agencyfaqs!. (2006, April 6). Kids' primetime on television same as adults: Survey. Retrieved from goo.gl/4ow3Al.

Agrawal, B. C. (1999). Children's television in India: A situational analysis. Delhi, India: Concept Publishing Company.

Ahmed, S., \& Wahab, J. A. (2014). Animation and socialization process: Gender role portrayal on Cartoon Network. Asian Social Science, 10(3), 44-53. 
Aubrey, J. S., \& Harrison, K. (2004). The gender-role content of children's favorite television programs and its links to their gender-related perceptions. Media Psychology, 6(2), 111-146.

Bhagia, R. (2013a, February 20). Calling kids. Retrieved from goo.gl/t5guJu.

Bhagia, R. (2013b, July 8). India's biggest cartoon success. Retrieved from goo.gl/PXnWp5.

Brooks, D. E., \& Hébert, L. P. (2006). Gender, race, and media representation. Handbook of Gender and Communication, 16, 297-317.

Chu, D., \& McIntyre, B. T. (1995). Sex role stereotypes on children's TV in Asia a content analysis of gender role portrayals in children's cartoons in Hong Kong. Communication Research Reports, 12(2), 206-219.

Comstock, G., \& Paik, H. (1991). Television and the American Child. San Diego, CA: Academic Press.

Davies, M. M. (2001). "Dear BBC": Children, Television Storytelling and the Public Sphere. Cambridge: Cambridge University Press.

Downs, A. C., \& Harrison, S. K. (1985). Embarrassing age spots or just plain ugly? Physical attractiveness stereotyping as an instrument of sexism on American television commercials. Sex roles, 13(1-2), 9-19.

Durkin, K. (1985). Television and sex-role acquisition 1: Content. British Journal of Social Psychology, 24(2), 101-113.

Eick, K. (1998). Gender stereotypes in children's television cartoons. Adolescence, 37(253), 7.

FICCI-KPMG. (2015). Indian media and entertainment industry report 2015. Retrieved from goo.gl/YoXpy5.

Fitzpatrick, M. J., \& McPherson, B. J. (2010). Coloring within the lines: Gender stereotypes in contemporary coloring books. Sex Roles, 62(1-2), 127-137.

Gerbner, G., Gross, L., Morgan, M., Signorielli, N., \& Shanahan, J. (2002). Growing up with television: Cultivation processes. Media effects: Advances in Theory and Research, 2, 43-67.

Greenwood, D. N., \& Lippman, J. R. (2010). Gender and media: Content, uses, and impact. In J. C. Chrisler, \& D. R. McCreary (eds.), Handbook of Gender Research in Psychology (pp. 643-669). New York: Springer.

Habib, K., \& Soliman, T. (2015). Cartoons' effect in changing children mental response and behavior. Open Journal of Social Sciences, 3(9), 248-264.

Halim, M. L., Ruble, D. N., \& Tamis-LeMonda, C. S. (2013). Four-year-olds' beliefs about how others regard males and females. British Journal of Developmental Psychology, 31(1), 128-135.

Hapkiewicz, W. G. (1979). Children's reactions to cartoon violence. Journal of Clinical Child \& Adolescent Psychology, 8(1), 30-34.

Holtzman, L., \& Sharpe, L. (2014). Media messages: What film, television, and popular music teach us about race, class, gender, and sexual orientation. New York: M. E. Sharpe.

India Infoline News Service. (2009). M.A.D. enters into new season. Retrieved from goo.gl/OmIzvQ.

India Infoline News Service. (2010, November 22). Kids spend 35 hours a week watching TV: ASSOCHAM survey. Retrieved from goo.gl/8IdmRu.

Kaur, R. (2013, May 4). Why kids love cartoons so much?. Retrieved from goo.gl/IzaGxJ.

Kini, S. (2016, March). Does children's television make business sense in India (Unpublished Master thesis). School of Communication, Flame University, India. Retrieved from goo.gl/V90jSz. 
Knorr, C. (2015). Why media role models matter. Retrieved from goo.gl/IzUf2X.

Kohli-Khandekar, V. (2014, October 2). Kids' channels grow up, but not the money. Retrieved from goo.gl/ofVNoy.

Lemish, D. (2007). Children and television: A global perspective. London: Blackwell Publications.

Mayes, S. L., \& Valentine, K. B. (1979). Sex role stereotyping in Saturday morning cartoon shows. Journal of Broadcasting \& Electronic Media, 23(1), 41-50.

McMillin, D., Götz, M., Hofmann, O., Dobler, S., Scherr, S., Bulla, C., \& Schreiner, M. (2008). Children's television worldwide: Gender representation in Indian children's television. Retrieved from goo.gl/CVebFd.

Merskin, D. L. (2008). Race and gender representations in advertising in cable cartoon programming. CLCWeb: Comparative Literature and Culture, 10(2).

Nikken, P., \& Peeters, A. L. (1988). Children's perceptions of television reality. Journal of Broadcasting \& Electronic Media, 32(4), 441-452.

Powell, K. A., \& Abels, L. (2002). Sex-roles stereotypes in TV programs aimed at the preschool audience: An analysis of Teletubbies and Barney \& Friends. Women and Language, 25(2), 14.

Preiss, R. W., Mae Gayle, B., Burrell, N., Allen, M., Bryant, J. (Eds.). (2007). Mass media effects research: Advances through meta-analysis. New York: Routledge.

Raghunath, A. (2012, June 27). Everybody loves Chhota Bheem. Retrieved from goo.gl/aFKIuz.

Rashid, A. (2015). Impact of television cartoon channels on children in India. Journal of Indian Research, 3(2), 64-72.

Roy, A. (2016, February). Shaktimaan: The cultural emergence of an Indian super hero. IOSR Journal of Humanities and Social Science, 21(2), 38-54.

Shehab, A. J. A. (2008). Gender and racial representation in children's television programming in Kuwait: Implications for education. Social Behavior and Personality: an international journal, 36(1), 49-64.

Sternglanz, S. H., \& Serbin, L. A. (1974). Sex role stereotyping in children's television programs. Developmental Psychology, 10(5), 710-715.

Thevar, V. (2014, May 11). Their toons, our talk. Retrieved from goo.gl/2CGYZY.

United Nations Development Programme - UNDP. (2015). Gender Inequality Index. Retrieved from goo.gl/zgiOML. 
